\begin{tabular}{|l|l|l|}
\hline \multicolumn{2}{|c|}{ PublisherInfo } \\
\hline \hline PublisherName & $:$ & BioMed Central \\
\hline \hline PublisherLocation & $:$ & London \\
\hline \hline PublisherImprintName & $:$ & BioMed Central \\
\hline \hline
\end{tabular}

\title{
Virus-induced RNA silencing
}

\begin{tabular}{|l|l|l||}
\hline \multicolumn{2}{|c|}{ ArticleInfo } \\
\hline \hline ArticleID & $:$ & 4484 \\
\hline \hline ArticleDOI & $:$ & $10.1186 /$ gb-spotlight-20020520-01 \\
\hline \hline ArticleCitationID & $:$ & spotlight-20020520-01 \\
\hline \hline ArticleSequenceNumber & $:$ & 150 \\
\hline \hline ArticleCategory & $:$ & Research news \\
\hline ArticleFirstPage & $:$ & 1 \\
\hline \hline ArticleLastPage & $:$ & 2 \\
\hline \hline & & RegistrationDate : 2002-5-20 \\
\hline ArticleHistory & $:$ & OnlineDate \\
\hline \hline ArticleCopyright & $:$ & BioMed Central Ltd2002-5-20 \\
\hline \hline ArticleGrants & $:$ & \\
\hline \hline ArticleContext & $:$ & 130593311 \\
\hline \hline
\end{tabular}




\section{Jonathan B Weitzman}

Email: jonathanweitzman@hotmail.com

RNA silencing processes result in the sequence-specific degradation of RNA and effective posttranscriptional gene silencing. In the May 17 ScienceHongwei Li and colleagues from the University of California, Riverside report that Flock House Virus (FHV) is both an initiator and a target of RNA silencing (Science 2002, 296:1319-1321). They noticed that $B 2$ gene of FHV resembles a plant virus gene encoding a silencing suppressor. Expression of the FHV B2 protein in plants prevented RNA silencing of a GFP transgene. FHV normally infects vertebrate and invertebrate animal hosts. Li et al. found that infection of Drosophila cells resulted in the production of FHV short-interfering RNA (siRNA). The RNA silencing machinery prevented FHV accumulation, indicating the FHV is also a target of RNA silencing. The FHV B2 protein suppresses RNA silencing and favours FHV

accumulation. These results provide evidence that RNA silencing is part of the innate immune response to viral infection in animals.

\section{References}

1. RNA silencing.

2. Science, $[\mathrm{http}: / / \mathrm{www}$. sciencemag.org]

3. University of California, Riverside, [http://www.ucr.edu] 